\title{
Original Paper \\ Special articles : Biomass \\ 特集：バイオマス \\ A Relationship between the Formation Rate of Solid Component and Volume Reduction of Packed Bed of Woody Biomass Particles during Pyrolysis

\author{
Ken-ichiro TANOUE ${ }^{* 1}$, Kei YAMASAKI*1, \\ Tatsuo NiSHIMURA * ${ }^{1}$, Miki TANIGUCHI ${ }^{* 2}$, and Ken-ichi SASAUCHI ${ }^{* 2}$ \\ (Received February 28, 2011)
}

\begin{abstract}
木質バイオマスの熱分解中に生じる減容過程と固形分生成速度との関係 田之上健一郎*1, 山崎 慶*1, 西村龍夫*1 , 谷口美希*2，笹内謙一*2
\end{abstract} \\ In this report, the yield of solid component undergoing the fast and slow pyrolysis in the packed bed of biomass particles has been compared with the analyzed one by the different three kinetic models (model-1: Thurner et.al, model-2: Mohan et.al, model-3: Miller et.al). From the results, the yield of solid component could be reproduced by the analysis using the model-3 even if the heating rate and the lignin content changed. Furthermore, the relationship between the volume reduction process in the packed bed and the chemical reaction undergoing pyrolysis was elucidated by the formularization. From the result, the volume in the packed bed of the biomass undergoing the pyrolysis can be estimated by using the model-3 and the depen- dence of gas volume in the bed on the temperature.
}

\section{Key Words}

Pyrolysis, Volume reduction, Lignin content, Packed bed

\section{1. 諸 言}

日本は国土の $67 \%$ が森林に囲まれており，重量換算で，人 工林からの林地残材 400 万t/year，天然林 1000 万t/year もの 森林が未利用のままである。最近では，未利用森林による木 質バイオマスエネルギー生成に高い関心が寄せられており, さまざまなガス化試験プラントが開発されている。今後，日 本のように急峻な山に囲まれている場合，木材の運搬コスト を低下させるために, 立地条件に適した規模のガス化プラン 卜を開発していくことが望まれる。特にプラントの中枢であ るガス化装置を設計する上で，反応を含むバイオマスの物質 伝達，バイオマスの熱伝達を知ることは重要である。

バイオマスは，熱分解によって，チャー，C1-C2系炭化水素 などのように中位発熱量をもつガス, 凝縮性有機化合物 (夕ー ル）が生成されることが知られており，これまでにバイオマ ス粒子内の素反応を含め，さまざまな化学反応モデルが提案 されている ${ }^{1)}$

* 1 Yamaguchi University

2-16-1, Ube-shi, Yamaguchi 755-8611, Japan

* 2 Chugai Ro Co.ltd

2-4, Chikko-Shinmachi, Nishi-ku, Sakai-shi, Osaka 592-8331, Japan
一方で，熱分解中の化学反応を考慮に入れた熱伝達特性に ついては, Koufopanos ら ${ }^{2)}$, Won ら ${ }^{3)}$ などさまざまな研究者 が取り組んでおり，シミュレーションによって予測できつつ ある4)。しかし，これらのモデルのほとんどは，バイオマス層 の体積は変化しないと仮定したものであり，バイオマス層と ガス層との界面を推定するときに重要になる減容過程につい ての考慮がなされていない。

著者らは，前報5)で，バイオマスの熱分解中に生じる減容 過程を可視化により明らかにし，減容を考慮した熱伝導計算 によって，バイオマス充填層内の伝熱特性はおおむね再現で きることを明らかにした。しかし，前報5)では，熱分解反応 を考慮しておらず，また減容過程と熱分解反応との関係は明 らかになっていない。

本研究では，これまでに我々が行ってきた低速熱分解実験 データ 5) および急速熱分解実験データ6) を用いて，既存の熱 分解モデルと固形分収率について比較・検討を行った。さら

* 1 山口大学大学院理工学研究科機械工学専攻 干 755-8611 山口県宇部市常盤台 2-16-1

*2 中外炉工業(株) 堺事業所エンジニアリングセンター 于 592-8331 堺市西区築港新町 2 丁 4 番 
に，それらの熱分解モデルを用いて，木質バイオマスの減容 過程がどのように再現できるかについて検討した。

\section{2. 実 験}

\section{1 実験試料}

バイオマス試料として米松のおがくず (平均径 $D_{\mathrm{p}}=1 \mathrm{~mm}$ ) またはバークのおがくず（平均径 $D_{\mathrm{p}}=0.5 \mathrm{~mm}$ ）を用いた。ま た，これらのバイオマス試料の組成は，Ayhanの論文 ${ }^{7)}$ から 引用し，それをTable 1に示した。ガス化の前処理として，バ イオマスは乾燥機によって $383 \mathrm{~K} て ゙ 120 \mathrm{~min}$ 乾燥させたもの を使用した。

\section{2 固形分の収率測定実験およびバイオマス層体積の可視 化実験}

2 つの熱分解実験 5) 6) で得られた固形分収率を用いた。1 つ目の急速熱分解実験 6$)$ は，予め所定の温度に設定した加熱 炉に， $W_{\mathrm{B} 0}=0.6 \mathrm{~g}$ のバイオマスを充填したステンレス製の籠 を挿入し， $t=5 \mathrm{~min}$ 後に籠を引き上げた。実験終了後，チャー の質量を測定した。また，2つめの低速熱分解実験5) は，可 視化空付きの加熱炉内に, $\left[W_{\mathrm{B} 0}\right]=9 \mathrm{~g}$ のバイオマス試料を充 填した石英ビーカーを設置し， $400^{\circ} \mathrm{C} / \mathrm{h}$ で設定温度まで $t=180$ min加熱した。実験中は，ビデオでバイオマス層を撮影し，画 像を 2 值化することによりバイオマス層の体積変化を調査し た。実験条件をTable 2に示した。さらに，反応モデルから固 形分収率を推定するためには，バイオマス充填層の温度が必 要である。本研究では，Fig.1に示したバイオマス充填層温度 の経時変化の実測デー夕を用いて解析を行った。なお，バイ オマス充填層温度は，1 S 拈き(急速熱分解)または $5 \mathrm{~s}$ 打き (低速熱分解)に計測しているため，それ以下のタイムステッ プごとの温度は, spline補間して求めた。そのほか, 詳細な実 験装置および手法については, 前報5)6で示したとおりである。

\section{3. 熱分解モデルおよび解析方法}

Table 3 に今回使用した反応モデルを示した。本研究では, Table 1でも示したように，リグニン含有量が大きく異なるバ
イオマス試料の固形分収率を測定した。このことを意識して, バイオマスの主要成分が考慮されたモデルと考慮されていな いモデルを選択した。Model-1は，バイオマスの熱分解反応を 示す一番典型的なモデル8) であり，木質バイオマスが，熱分 解によってガス, タール, チャーがそれぞれ並列反応で生成 されるとしたものである。反応速度定数もいくつか提案され ているが，本研究では，Di Blasiらが提案した值9)を使用した。 Model-2 ${ }^{10)}$, Model-3 ${ }^{11)}$ は，木質バイオマスの主要成分である ヘミセルロース，セルロース，リグニンがそれぞれ並列に熱 分解するとしたものであり, 固形分の最終収率を意識したモ デルである。Model-2中のへミセルロースの熱分解モデルおよ

a) Fast pyrolysis

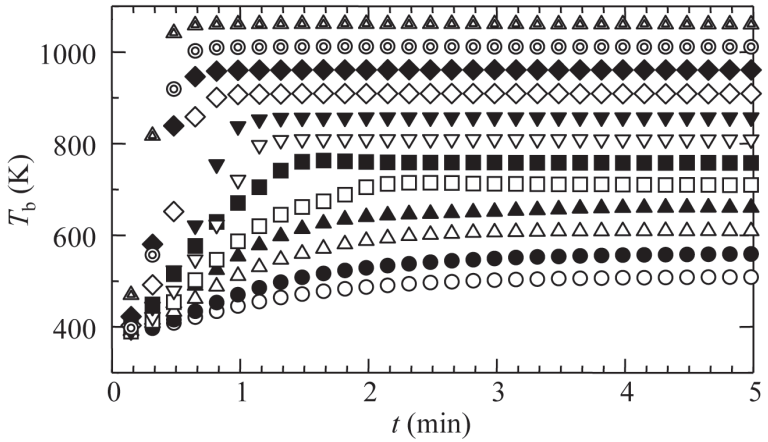

b) Slow pyrolysis

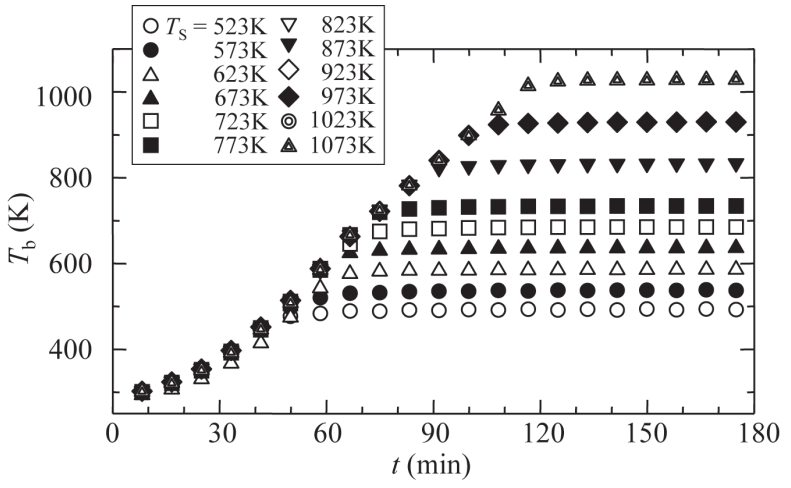

Fig. 1 Time course of the temperature in the packed bed of biomass particles undergoing the pyrolysis

Table 1 Properties of biomass

\begin{tabular}{c|c|c|c|c|c|c|c|c|c}
\hline True density of wood $\left(\mathrm{g} / \mathrm{cm}^{3}\right)$ & $\rho_{\mathrm{T}}$ & \multicolumn{9}{|c}{1.5} \\
\hline Kind of biomass & - & \multicolumn{3}{|c|}{ Sawdust of Pseudotsuga menziesii } & \multicolumn{5}{c}{ Sawdust of Wood bark } \\
\hline Size of biomass particles $(\mathrm{mm})$ & Dp & \multicolumn{3}{|c|}{1} & & \multicolumn{5}{c}{0.5} \\
\hline Component & - & Hemicellulose & Cellulose & Lignin & Ash & Hemicellulose & Cellulose & Lignin & Ash \\
\hline Mass fraction (wt\%) & $w_{\mathrm{i}}$ & 24.4 & 45.8 & 28.0 & 1.7 & 29.8 & 24.8 & 43.8 & 1.6 \\
\hline
\end{tabular}

Table 2 Experimental conditions

\begin{tabular}{lccc}
\hline Initial weight of packed bed of biomass $(\mathrm{g})$ & $\mathrm{W}_{\mathrm{B} 0}$ & 0.6 & 9 \\
Initial volume of packed bed of biomass $\left(\mathrm{cm}^{3}\right)$ & $\mathrm{V}_{\mathrm{PB}, 0}$ & 2.6 & 58.9 (Pseudotsuga menziesii) \\
& & & 36.1 ( Wood bark) \\
Setting temperature (K) & $T_{\mathrm{S}}$ & $523-1073$ & $523-1073$ \\
Operation time (min) & $t$ & 5 & 180 \\
\hline
\end{tabular}


Table 3 Reaction models for wood pyrolysis

\begin{tabular}{|c|c|c|c|}
\hline Model & & Reaction rate (kg/s) & Ref. \\
\hline-1 & Wood $\sum_{R_{3}}^{R_{1} R_{2}} \underset{\text { Tar }}{\text { Gas }}$ & $\begin{array}{l}R_{1}=3.27 \times 10^{6} \exp \left(-111700 / \mathrm{R}_{\mathrm{g}} / T\right)[W]_{\mathrm{m} 1} \\
R_{2}=1.08 \times 10^{10} \exp \left(-148000 / \mathrm{R}_{\mathrm{g}} / T\right)[W]_{\mathrm{m} 1} \\
R_{3}=4.38 \times 10^{9} \exp \left(-152700 / \mathrm{R}_{\mathrm{g}} / T\right)[W]_{\mathrm{m} 1} \\
R_{\mathrm{W}}=\mathrm{d}[W]_{\mathrm{m} 1} / \mathrm{d} t=-\left(R_{1}+R_{2}+R_{3}\right) \\
R_{\mathrm{C}}=\mathrm{d}[C]_{\mathrm{m} 1} / \mathrm{d}_{\mathrm{t}}=R_{3}\end{array}$ & $\begin{array}{l}\text { 8) } \\
9)\end{array}$ \\
\hline-2 & 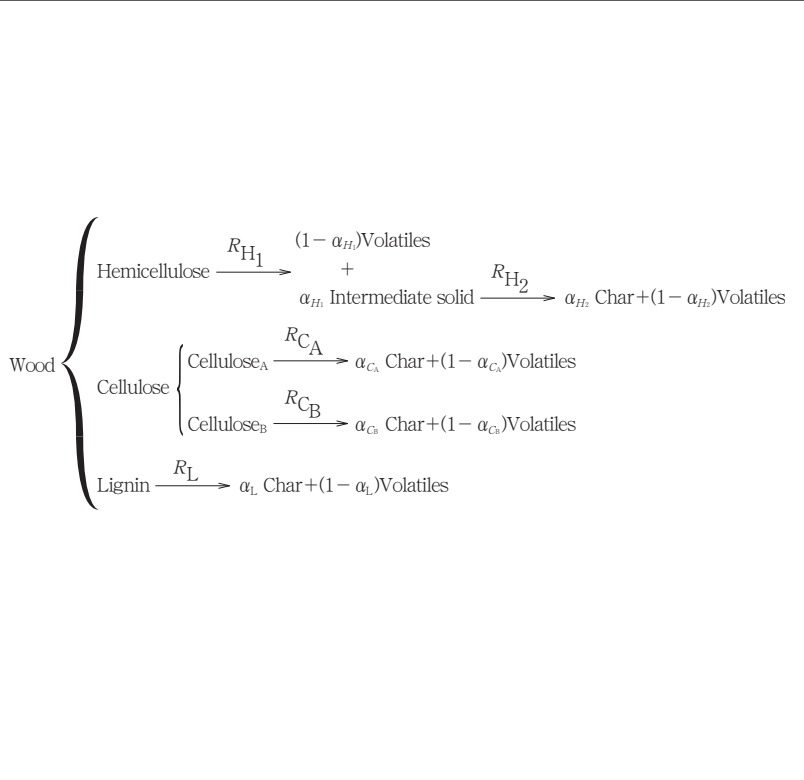 & $\begin{array}{l}R_{\mathrm{H} 1}=7.94 \times 10^{16} \exp \left(-195000 / \mathrm{R}_{\mathrm{g}} / T\right)[H]_{\mathrm{m} 2} \\
R_{\mathrm{H} 2}=1.26 \times 10^{7} \exp \left(-96000 / \mathrm{R}_{\mathrm{g}} / T\right)[I S]_{\mathrm{m} 2} \\
R_{\mathrm{H}}=\mathrm{d}[H]_{\mathrm{m} 2} / \mathrm{dt}=-R_{\mathrm{H} 1} \\
R_{\mathrm{IS}}=\mathrm{d}[I S]_{\mathrm{m} 2} / \mathrm{dt}=\alpha_{\mathrm{H} 1} R_{\mathrm{H} 1}-R_{\mathrm{H} 2} \\
R_{\mathrm{Char}, \mathrm{H}}=\mathrm{d}\left[C_{\mathrm{H}}\right]_{\mathrm{m} 2} / \mathrm{d} t=\alpha_{\mathrm{H} 2} R_{\mathrm{IS}} \\
R_{\mathrm{CA} 1}=7.94 \times 10^{16} \exp \left(-202650 / \mathrm{R}_{\mathrm{g}} / T\right) \\
\quad \times\left[C e l_{\mathrm{A}, 0}\right]_{\mathrm{m} 2}\left(\left[C e l_{\mathrm{A}}\right]_{\mathrm{m} 2} /\left[C e l_{\mathrm{A}, 0}\right]_{\mathrm{m} 2}\right) \\
\quad \times\left(1-\left[C e l_{\mathrm{A}}\right]_{\mathrm{m} 2} /\left[C e l_{\mathrm{A}, 0}\right]_{\mathrm{m} 2}\right)^{0.481} \\
R_{\mathrm{CA}}=\mathrm{d}\left[C e l_{\mathrm{A}}\right]_{\mathrm{m} 2} / \mathrm{d} t=-R_{\mathrm{CA} 1} \\
R_{\mathrm{Char}, \mathrm{CA}}=\mathrm{d}\left[C C_{\mathrm{C}, \mathrm{A}}\right]_{\mathrm{m} 2} / \mathrm{d} t=\alpha_{\mathrm{CA}} R_{\mathrm{CA} 1} \\
R_{\mathrm{CB} 1}=1.26 \times 10^{7} \exp \left(-255000 / \mathrm{R}_{\mathrm{g}} / T\right) \\
\quad \times\left[C e l_{\mathrm{B}, 0}\right]_{\mathrm{m} 2}\left(\left[C e l_{\mathrm{B}}\right]_{\mathrm{m} 2} /\left[C e l_{\mathrm{B}, 0}\right]_{\mathrm{m} 2}\right)^{22} \\
\left.\quad \times\left(1-\left[C e l_{\mathrm{B}}\right]_{\mathrm{m} 2} / C e l_{\mathrm{B}, 0}\right]_{\mathrm{m} 2}\right) \\
R_{\mathrm{CB}}=\mathrm{d}\left[C e l_{\mathrm{B}}\right]_{\mathrm{m} 2} / \mathrm{d} t=-R_{\mathrm{CB} 1} \\
R_{\mathrm{Char}, \mathrm{CB}}=\mathrm{d}\left[C C_{\mathrm{C}, \mathrm{B}}\right]_{\mathrm{m} 2} / \mathrm{d} t \alpha_{\mathrm{CA}} R_{\mathrm{CB} 1} \\
R_{\mathrm{L} 1}=5.09 \times 10^{5} \exp \left(-95000 / \mathrm{R}_{\mathrm{g}} / T\right)[L]_{\mathrm{m} 2} \\
R L=\mathrm{d}[L]_{\mathrm{m} 2} / \mathrm{d} t=-R_{\mathrm{L} 1} \\
R_{\mathrm{Char}, \mathrm{L}}=\mathrm{d}\left[C_{\mathrm{L}}\right]_{\mathrm{m} 2} / \mathrm{d} t=\alpha_{\mathrm{L}} R_{\mathrm{L} 1}\end{array}$ & $\begin{array}{l}\text { 10) } \\
\text { 12) } \\
\text { 13) } \\
\text { 14) }\end{array}$ \\
\hline-3 & 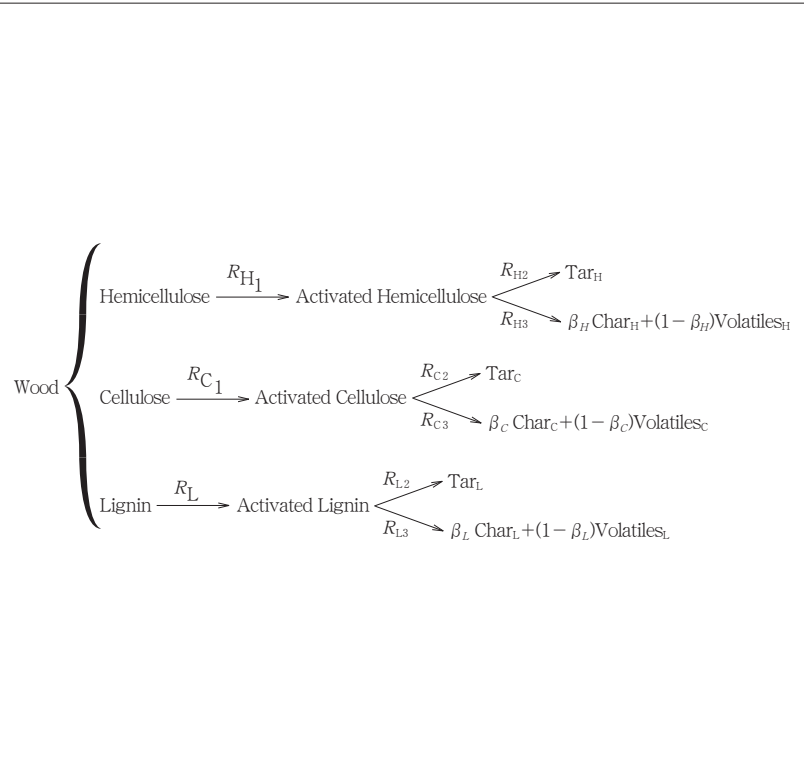 & $\begin{array}{l}R_{\mathrm{H} 1}=2.10 \times 10^{16} \exp \left(-186700 / \mathrm{R}_{\mathrm{g}} / T\right)[H]_{\mathrm{m} 3} \\
R_{\mathrm{H} 2}=8.75 \times 10^{15} \exp \left(-202400 / \mathrm{R}_{\mathrm{g}} / T\right)[A H]_{\mathrm{m} 3} \\
R_{\mathrm{H} 3}=2.60 \times 10^{11} \exp \left(-145700 / \mathrm{R}_{\mathrm{g}} / T\right)[A H]_{\mathrm{m} 3} \\
R_{\mathrm{H}}=\mathrm{d}[H]_{\mathrm{m} 3} / \mathrm{d} t=-R_{\mathrm{H} 1} \\
R_{\mathrm{AH}}=\mathrm{d}[A H]_{\mathrm{m} 3} / \mathrm{d} t=R_{\mathrm{H} 1}-R_{\mathrm{H} 2}-R_{\mathrm{H} 3} \\
R_{\mathrm{Char}, \mathrm{H}}=\mathrm{d}\left[C_{\mathrm{H}}\right]_{\mathrm{m} 3} / \mathrm{d} t=\beta_{\mathrm{H}} R_{\mathrm{H} 2} \\
R_{\mathrm{C} 1}=2.80 \times 10^{19} \exp \left(-242400 / \mathrm{R}_{\mathrm{g}} / T\right)[C e 1]_{\mathrm{m} 3} \\
R_{\mathrm{C} 2}=3.28 \times 10^{14} \exp \left(-196500 / \mathrm{R}_{\mathrm{g}} / T\right)[A C]_{\mathrm{m} 3} \\
R^{\mathrm{C} 3}=1.30 \times 10^{10} \exp \left(-150500 / \mathrm{R}_{\mathrm{g}} / T\right)[A C]_{\mathrm{m} 3} \\
R_{\mathrm{C}}=\mathrm{d}[C e 1]_{\mathrm{m} 3} / \mathrm{d} t=-R_{\mathrm{C} 1} \\
R_{\mathrm{AC}}=\mathrm{d}[A C]_{\mathrm{m} 3} / \mathrm{d} t=R_{\mathrm{C} 1}-R_{\mathrm{C} 2}-R_{\mathrm{C} 3} \\
R_{\mathrm{Char}, \mathrm{C}}=\mathrm{d}\left[C_{\mathrm{C}}\right]_{\mathrm{m} 3} / \mathrm{d} t=\beta_{\mathrm{C}} R_{\mathrm{C} 2} \\
R_{\mathrm{L} 1}=9.60 \times 10^{8} \exp \left(-107600 / \mathrm{R}_{\mathrm{g}} / T\right)[L]_{\mathrm{m} 3} \\
R_{\mathrm{L} 2}=1.50 \times 10^{9} \exp \left(-143800 / \mathrm{R}_{\mathrm{g}} / T\right)[A L]_{\mathrm{m} 3} \\
R_{\mathrm{L} 3}=7.70 \times 10^{6} \exp \left(-111400 / \mathrm{R}_{\mathrm{g}} / T\right)[A L]_{\mathrm{m} 3} \\
R_{\mathrm{L}}=\mathrm{d}[L]_{\mathrm{m} 3} / \mathrm{d} t=-R_{\mathrm{L} 1} \\
R_{\mathrm{AL}}=\mathrm{d}[A L]_{\mathrm{m} 3} / \mathrm{d} t=R_{\mathrm{L} 1}-R_{\mathrm{L} 2}-R_{\mathrm{L} 3} \\
R_{\mathrm{Char}, \mathrm{L}}=\mathrm{d}[C \mathrm{~L}]_{\mathrm{m} 3} / \mathrm{d} t=\beta_{\mathrm{L}} R_{\mathrm{L} 2}\end{array}$ & 11) \\
\hline
\end{tabular}

び速度パラメータはV Varhegyi らによって提案された值 ${ }^{12)}$ を, セルロースの熱分解モデルおよび速度パラメー夕はCapartら によって提案された值 ${ }^{13)}$ を，七ルロースの熱分解モデルおよ び速度パラメータはChan らによって提案された值 ${ }^{14)}$ をそれ ぞれ用いた。また, Table 3中の Model-2, Model-3中に示され ているパラメータをTable 4に示した。 Model-2では，セルロー スが速く熱分解するものと遅く熱分解するものとに分けられ ている ${ }^{14)}$ 。この構成比は, Table 4 中の $\mathrm{f}_{\mathrm{CA}, 0}$ および $\mathrm{f}_{\mathrm{CB}, 0}$ で示し た。今回は, タールの気相 2 次分解によるチャー生成の影響 は無視した。解析は，4次のルンゲクッタ法を用いて時間積
Table 4 Parameters of the reaction models

\begin{tabular}{cccc}
\hline Model & Parameters & Value & Reference \\
\hline-2 & $\alpha_{\mathrm{H} 1}$ & 0.56 & \\
& $\alpha_{\mathrm{H} 2}$ & 0.45 & \\
& $\alpha_{\mathrm{CA}}$ & 0.087 & $12)$ \\
& $\alpha_{\mathrm{CB}}$ & 0.087 & $13)$ \\
& $f_{\mathrm{CA} 0}$ & 0.821 & $14)$ \\
& $f_{\mathrm{CB} 0}$ & 0.179 & \\
$-------\alpha_{\mathrm{L}}----\frac{3}{-}-$ & - & - \\
-3 & $\beta_{\mathrm{H}}$ & 0.60 & $11)$ \\
& $\beta_{\mathrm{C}}$ & 0.35 & \\
\hline & $\beta_{\mathrm{L}}$ & 0.75 & \\
\hline
\end{tabular}


分を行い，それぞれのModel，それぞれの設定温度ごとに次式 に基づいて固形分質量を算出した。

$$
\left\{\begin{array}{c}
\text { For model-1 } \\
{\left[\mathrm{S}_{\mathrm{B}}\right]=\left[W_{\mathrm{B}}\right]_{\mathrm{m} 1}+[C]_{\mathrm{m} 1}} \\
\text { For model-2 } \\
{\left[\mathrm{S}_{\mathrm{B}}\right]=[\mathrm{H}]_{\mathrm{m} 2}+[\mathrm{IS}]_{\mathrm{m} 2}+\left[\mathrm{CH}_{\mathrm{H}}\right]_{\mathrm{m} 2}} \\
+\left[\mathrm{Cel}_{\mathrm{A}}\right]_{\mathrm{m} 2}+\left[\mathrm{CC}, \mathrm{A}_{\mathrm{A} 2}\right]_{\mathrm{m} 2} \\
+\left[\mathrm{Cel}_{\mathrm{B}}\right]_{\mathrm{m} 2}+\left[\mathrm{CC}, \mathrm{B}_{\mathrm{m} 2}\right. \\
+[\mathrm{L}]_{\mathrm{m} 2}+\left[\mathrm{Cl}_{\mathrm{L}}\right]_{\mathrm{m} 2}
\end{array}\right.
$$

For model-3

$$
\begin{aligned}
& {\left[\mathrm{S}_{\mathrm{B}}\right]=[H]_{\mathrm{m} 3}+[A H]_{\mathrm{m} 3}+\left[C_{\mathrm{H}}\right]_{\mathrm{m} 3}} \\
& \quad+[\mathrm{Cel}]_{\mathrm{m} 3}+[A H]_{\mathrm{m} 3}+\left[C_{\mathrm{C}}\right]_{\mathrm{m} 3} \\
& +[L]_{\mathrm{m} 3}+[A L]_{\mathrm{m} 3}+\left[C_{\mathrm{L}}\right]_{\mathrm{m} 3}
\end{aligned}
$$

さらに次式によって固形分収率を算出し, 実験值との比較を 行った。

$$
y_{\mathrm{S}}=\frac{\left[S_{\mathrm{B}}\right]}{\left[W_{\mathrm{B}, 0}\right]}
$$

なお, model-2, model-3におけるへミセルロース，セルロー スおよびリグニンの質量の初期值は，Table 1に示した質量分 率に初期質量 $\left[W_{\mathrm{B}, 0}\right]$ をかけた值を用いた。タイムステップは, 急激な熱分解を考慮して $10^{-3} \mathrm{~S}$ (急速熱分解) または $10^{-2} \mathrm{~S}$ （低 速熱分解）とした。

\section{4. 結果および考察}

4.1 固形分収率の実験結果と各反応モデルによる解析結果 との比較

Fig. 2に設定温度に対する固形分収率の変化を示した。Fig.

a) $W_{0}=0.6 \mathrm{~g}$, Fast Pyrolysis, Pseudotsuga menziesii

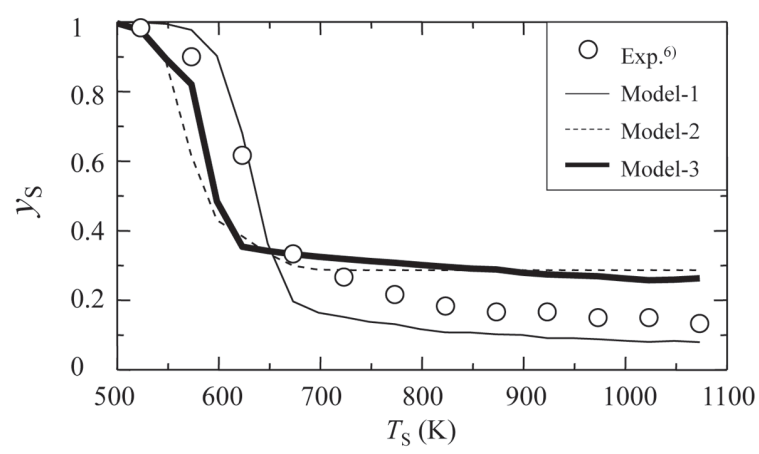

b) $W_{0}=9 \mathrm{~g}$, Slow Pyrolysis, Pseudotsuga menziesii

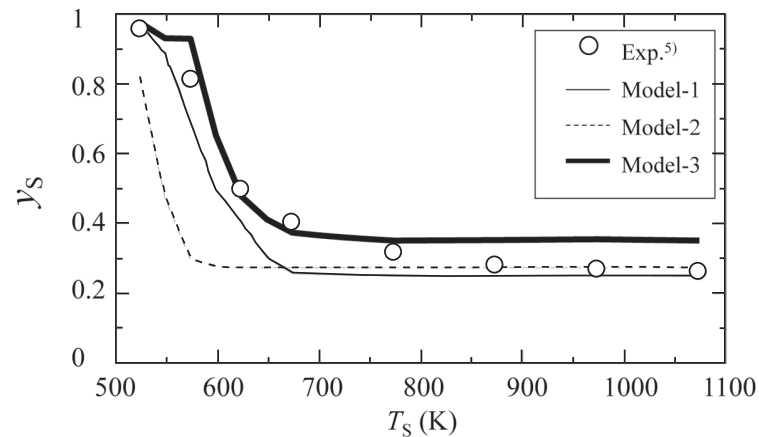

2aは，米松のおがくずを用いて急速熱分解を行ったものであ り，いずれの反応モデルでも設定温度に対する固形分収率の 分布形状を概ね再現できていることがわかる。Fig. $2 \mathrm{~b}$ に示す ように，米松のおがくずの低速熱分解による固形分収率は, Model-1でも Model-3でも実験值を概ね再現可能であった。し たがって，米松のおがくずの熱分解は，Model-1またはModel3 の反応モデルに近いことが示唆される。一方, Figs. $2 \mathrm{c}, 2 \mathrm{~d}$ に示すように，バークの固形分収率は，昇温速度の違いによ らず，バイオマス中のリグニン量を考慮できるModel-3の反応 モデルによって再現できることがわかった。

以上より，本研究範囲に扔ける熱分解による固形分収率は, 昇温速度やバイオマス中のリグニン量によらず，Model-3を用 いた解析によって再現可能であることが示された。

\section{2 減容過程と反応モデルとの関係}

Table 5 に, 熱分解前後におけるバイオマス充填層の質量, 体積, 見かけ密度および空隙率の実験結果を示した。空隙率 は，見かけ密度および真密度を用いて次式で算出した。

$$
\varepsilon \mathrm{PB}=1-\frac{\rho_{\mathrm{app}}}{\rho_{\mathrm{t}}}
$$

Table 5より，いずれの条件においても，充填層の空隙率は熱 分解後に増加していることがわかる。これは，熱分解進行中 に，バイオマス粒子中の細孔数が増大したものと考えられる。 バイオマス粒子の真密度を一定と仮定すれば，増加した細孔 数の体積は，バイオマス充填層内のガス体積に含まれること になる。本研究では, バイオマス細孔についての詳細には触 れずに，バイオマス層充填層のガス体積, $V_{\mathrm{G}}\left(\mathrm{cm}^{3}\right)$ とバイオ

c) $W_{0}=0.6 \mathrm{~g}$, Fast Pyrolysis, Bark

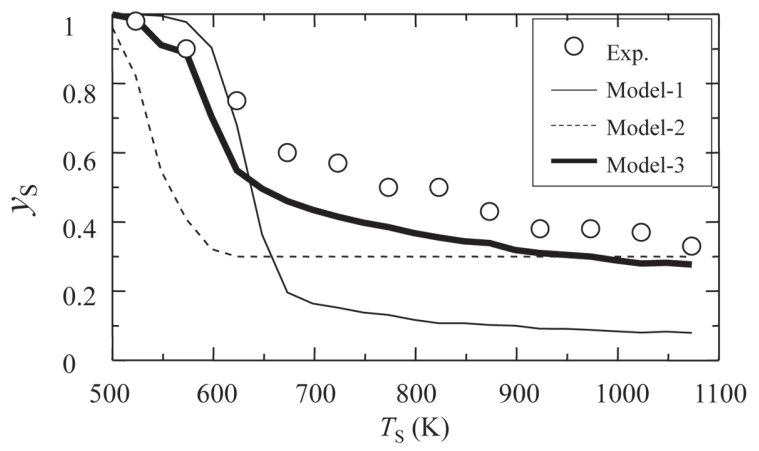

d) $W_{0}=9 \mathrm{~g}$, Slow Pyrolysis, Bark

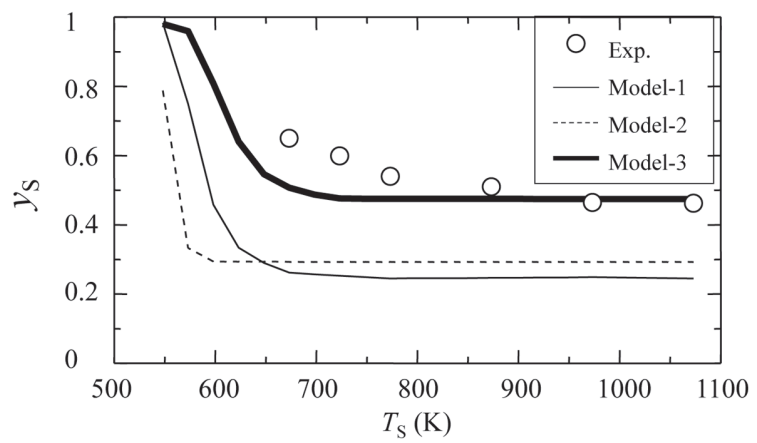

Fig. 2 Comparison of the experimental solid yield with the predicted one by three different kinetic models 
Table 5 Properties of packed bed of biomass before and after pyrolysis

\begin{tabular}{cccccccccc}
\hline \multirow{2}{*}{$\begin{array}{c}\text { Kind of } \\
\text { biomass }\end{array}$} & $T_{S}(\mathrm{~K})$ & $\begin{array}{c}W_{B} \\
(\mathrm{~g})\end{array}$ & $\begin{array}{c}V_{\mathrm{PB}} \\
\left(\mathrm{cm}^{3}\right)\end{array}$ & $\begin{array}{c}\rho_{\text {app }} \\
\left(\mathrm{g} / \mathrm{cm}^{3}\right)\end{array}$ & $\begin{array}{c}\varepsilon \text { PB } \\
(-)\end{array}$ & $\begin{array}{c}W_{B} \\
(\mathrm{~g})\end{array}$ & $\begin{array}{c}V_{\mathrm{PB}} \\
\left(\mathrm{cm}^{3}\right)\end{array}$ & $\begin{array}{c}\rho_{\text {app }} \\
\left(\mathrm{g} / \mathrm{cm}^{3}\right)\end{array}$ & $\begin{array}{c}\varepsilon \text { PB } \\
(-)\end{array}$ \\
\hline $\begin{array}{c}\text { Pseudotsuga } \\
\text { menziesii }\end{array}$ & 523 & 9 & 58.9 & 0.153 & 0.899 & 8.62 & 58.9 & 0.146 & 0.903 \\
& 573 & 9 & 58.9 & 0.153 & 0.899 & 7.31 & 55.0 & 0.133 & 0.912 \\
& 623 & 9 & 58.9 & 0.153 & 0.899 & 3.63 & 39.2 & 0.093 & 0.939 \\
& 673 & 9 & 58.9 & 0.153 & 0.899 & 3.63 & 36.8 & 0.098 & 0.935 \\
& 773 & 9 & 58.9 & 0.153 & 0.899 & 2.86 & 30.5 & 0.094 & 0.938 \\
& 873 & 9 & 58.9 & 0.153 & 0.899 & 2.52 & 25.7 & 0.098 & 0.935 \\
& 973 & 9 & 58.9 & 0.153 & 0.899 & 2.41 & 24.4 & 0.099 & 0.935 \\
& 1073 & 9 & 58.9 & 0.153 & 0.899 & 2.35 & 23.7 & 0.099 & 0.935 \\
\hline \multirow{2}{*}{ Wood bark } & 673 & 9 & 36.1 & 0.249 & 0.834 & 5.85 & 33.3 & 0.176 & 0.883 \\
& 723 & 9 & 36.1 & 0.249 & 0.834 & 5.39 & 31.8 & 0.170 & 0.887 \\
& 773 & 9 & 36.1 & 0.249 & 0.834 & 4.86 & 28.7 & 0.170 & 0.887 \\
& 873 & 9 & 36.1 & 0.249 & 0.834 & 4.59 & 28.4 & 0.162 & 0.892 \\
& 973 & 9 & 36.1 & 0.249 & 0.834 & 4.18 & 27.6 & 0.152 & 0.899 \\
& 1073 & 9 & 36.1 & 0.249 & 0.834 & 4.16 & 27.0 & 0.154 & 0.897 \\
\hline
\end{tabular}

マスの固形分の体積， $V_{\mathrm{B}}\left(\mathrm{cm}^{3}\right)$ とを別々に算出し，バイオマ ス充填層体積， $V_{\mathrm{PB}}\left(\mathrm{cm}^{3}\right)$ を見積もることとした。バイオマス 充填層体積は,

$$
V_{\mathrm{PB}}=V_{\mathrm{G}}+V_{\mathrm{B}}
$$

で表せる。両辺を $V_{\mathrm{PB}, 0}$ で割ると，

$$
\frac{V_{\mathrm{PD}}}{V_{\mathrm{PB}, 0}}=\frac{V_{\mathrm{G}}}{V_{\mathrm{PB}, 0}}+\frac{V_{\mathrm{B}}}{V_{\mathrm{PB}, 0}}
$$

まず，ガス体積 $V_{\mathrm{G}}$ は，Table 5 中の $\varepsilon$ PB および $V_{\mathrm{PB}}\left(\mathrm{cm}^{3}\right)$ を 用いて算出し，それを $V_{\mathrm{PB}, 0}$ で規格化した結果を Fig. 3 に示し た。これより, ガス体積の温度依存性は,

For Psudotsuga menziesii

$$
\frac{V_{\mathrm{G}}}{V_{\mathrm{PB}, 0}}= \begin{cases}0.899 & \left(T_{\mathrm{S}} \leqq 532 K\right) \\ 0.344+12.6 * \exp \left(-\frac{T_{\mathrm{S}}}{171}\right) & \left(T_{\mathrm{S}} \leqq 532 K\right)\end{cases}
$$

For bark

$$
\frac{V_{\mathrm{G}}}{V_{\mathrm{PB}, 0}}=\left\{\begin{array}{lr}
0.833 & \left(T_{\mathrm{S}} \leqq 665 K\right) \\
0.672+108 * \exp \left(-\frac{T_{\mathrm{S}}}{102}\right) & \left(T_{\mathrm{S}} \leqq 665 K\right)
\end{array}\right.
$$

のように近似できる。

一方，バイオマスの固形分質量， $\left[S_{B}\right](\mathrm{g})$ は，バイオマスの 固形分の体積, $V_{\mathrm{B}}\left(\mathrm{cm}^{3}\right)$ と真密度, $\rho_{\mathrm{t}}\left(=1.5 \mathrm{~g} / \mathrm{cm}^{3}\right)$ を用い て次式で表される。

$$
\left[S_{\mathrm{B}}\right]=\rho_{\mathrm{t}} V_{\mathrm{B}}
$$

熱分解中にバイオマス粒子の真密度が変化しなければ，バイ オマスの固形分の体積と質量との関係は

$$
\frac{V_{\mathrm{B}}}{V_{\mathrm{B}, 0}}=\frac{\left[S_{\mathrm{B}}\right]}{\left[W_{\mathrm{B}, 0}\right]}
$$

となり，熱分解反応による質量変化を用いてバイオマスの総 体積を算出できる。ここで， $V_{\mathrm{B} 0}$ : 熱分解前のバイオマス総体 積 $\left(\mathrm{cm}^{3}\right),\left[W_{\mathrm{B}, 0}\right]$ : 熱分解前のバイオマス総質量 $(\mathrm{g})$ である。 (6)，（8)式を(5)式に代入すると，バイオマス充填層体積は
For Psudotsuga menziesii

$$
\frac{V_{\mathrm{PB}}}{V_{\mathrm{PB}, 0}} \begin{cases}\frac{V_{\mathrm{PB}}}{V_{\mathrm{PB}, 0}} \frac{\left[S_{\mathrm{B}}\right]}{\left[W_{\mathrm{B}, 0}\right]}+0.899 & \left(T_{S} \leqq 532 K\right) \\ \frac{V_{\mathrm{PB}}}{V_{\mathrm{PB}, 0}} \frac{\left[S_{\mathrm{B}}\right]}{\left[W_{\mathrm{B}, 0}\right]} & \\ +0.344+12.6 * \exp \left(-\frac{T_{\mathrm{S}}}{171}\right) & \left(T_{S} \leqq 532 K\right)\end{cases}
$$

For bark

$$
\frac{V_{\mathrm{PB}}}{V_{\mathrm{PB}, 0}} \begin{cases}\frac{V_{\mathrm{PB}}}{V_{\mathrm{PB}, 0}} \frac{\left[S_{\mathrm{B}}\right]}{\left[W_{\mathrm{B}, 0}\right]}+0.833 & \left(T_{S} \leqq 665 K\right) \\ \frac{V_{\mathrm{PB}}}{V_{\mathrm{PB}, 0}} \frac{\left[S_{\mathrm{B}}\right]}{\left[W_{\mathrm{B}, 0}\right]} & \\ +0.672+108 * \exp \left(-\frac{T_{\mathrm{S}}}{102}\right) & \left(T_{S} \leqq 665 K\right)\end{cases}
$$

で表される。解析は 4 次のルンゲクッ夕法を用いて熱分解速 度の時間積分を行い，バイオマス質量 $\left[S_{B}\right]$ をもとめた。さら に，この時刻におけるバイオマス充填層温度をTsに代入する ことにより，(9)式からバイオマス充填層体積を求めた。

Fig. 4に低速熱分解の場合のバイオマス充填層体積の経時変 化を示した。プロット点は実験結果であり, ラインは解析結 果を示す。Fig. 4aは，米松の場合であり, Model-1, Model-3の いずれの場合でも，実験結果を再現できることがわかった。ま た, Fig. 4bは, バークの場合であり, Model-3を用いた解析に よって実験結果を再現できることがわかった。従って，本研 究範囲における熱分解による減容過程は, 昇温速度やバイオ マス中のリグニン量によらず，Model-3と充填層内のガス体積 の温度依存性を考慮することで再現可能であることが示され た。

本研究で提案した減容モデルは，同程度の粒子径の米松や バーク粒子を用いたとき，粒子相体積とガス相体積は相対的 に変化すると考えられるため, 充填層の大きさを変更した場 
a) Pseudotsuga menziesii

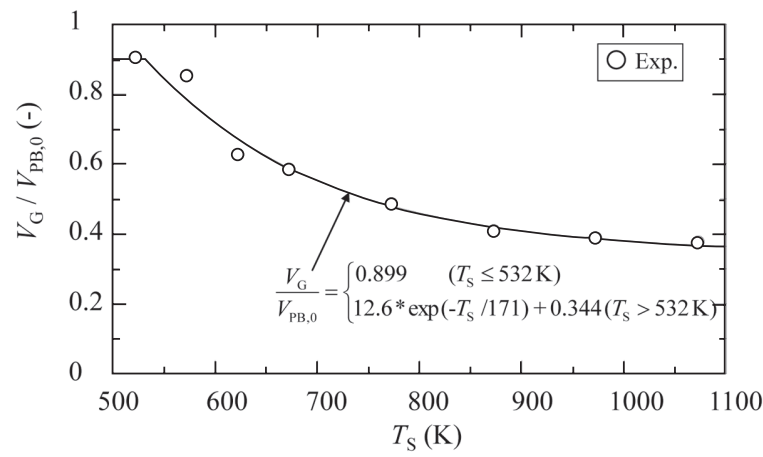

b) Bark

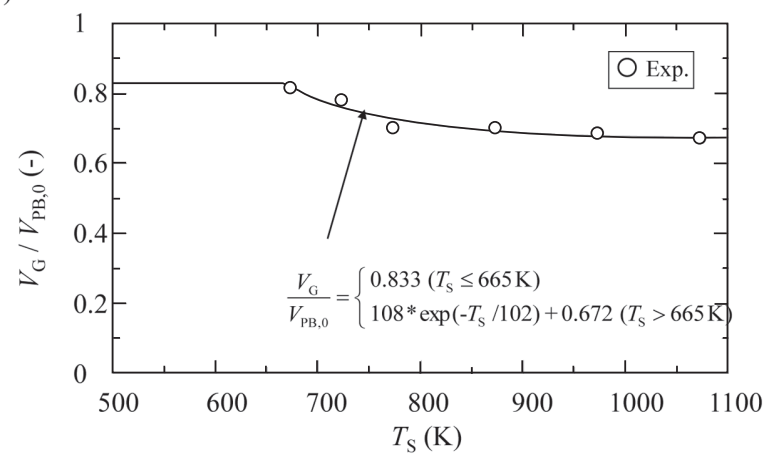

Fig. 3 Dependence of estimated gas volume in the packed bed of the biomass particles on the setting temperature

a) Pseudotsuga menziesii

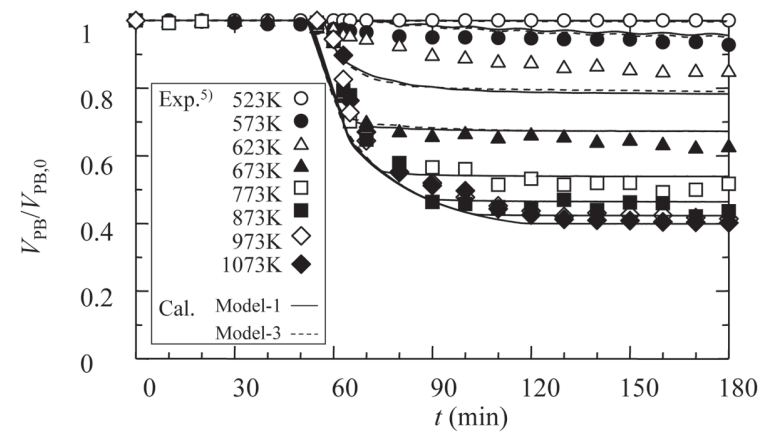

b) Bark

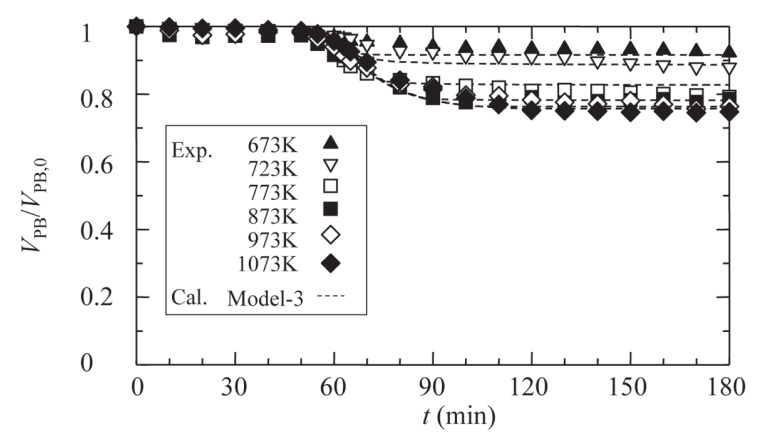

Fig. 4 Time course of the volume reduction process undergoing the pyrolysis

合にも応用可能である。

\section{5. 結 論}

木質バイオマスの熱分解に扮ける固形分収率について，3 つの熱分解モデル (model-1:Thurnerらによるモデル, model-
2:Mohan らによるモデル, model-3：Miller らによるモデル） を用いて実験との比較を行った。その結果，バイオマス中の リグニン量や昇温速度によらず，model-3を用いた解析によっ て，実験結果を再現できることがわかった。さらに，減容過 程と熱分解反応との関係を定式化することによって明らかに

した。その結果，バイオマス充填層の体積は, model-3の反応 モデルとバイオマス層充填層内のガス体積の温度依存性を考 慮することで再現できることがわかった。

\section{謝 辞}

本研究の一部は, 文部科学省「科学研究費 基盤 (C) No. 1956174」ならびにJSPS Core-To-Core program (No. 18004) の 支援を受けた。実験は，ウィディアウィジャヤンティ氏，川 中隆司氏，末富喬大氏，日名内竜也氏によって行われた。ま た，本研究を遂行するに当たり，宇部興産 宇部研究所 横田 守久氏の助言を頂いた。ここに記して謝意を表す。

\section{Nomenclature}

$[A C]_{\mathrm{m} 3}$ Weight of activated cellulose in model-3

$[\mathrm{g}]$

$[A H]_{\mathrm{m} 3}$ Weight of activated hemicellulose in model-3 $[\mathrm{g}]$

$[A L]_{\mathrm{m} 3}$ Weight of activated lignin in model-3 $\quad[\mathrm{g}]$

$[C]_{\mathrm{m} 1} \quad$ Weight of char in model-1 [g]

$[\mathrm{Cel}]_{\mathrm{m} 3}$ Weight of cellulose in model-3 [g]

$\left[\mathrm{Cel}_{\mathrm{A}}\right]_{\mathrm{m} 2}$ Weight of cellulose A in model-2 [g]

$\left[\mathrm{Cel}_{\mathrm{B}}\right]_{\mathrm{m} 2}$ Weight of cellulose B in model-2 [g]

$[C \mathrm{c}]_{\mathrm{m} 3}$ Weight of char formed by the decomposition of cellulose in model-3

$\left[C_{\mathrm{C}, \mathrm{A}}\right]_{\mathrm{m} 2}$ Weight of char formed by the decomposition of celluloseA in model-2

$\left[C_{\mathrm{C}, \mathrm{B}}\right]_{\mathrm{m} 2}$ Weight of char formed by the decomposition of celluloseB in model-2

$\left[\mathrm{CH}_{\mathrm{H}}\right]_{i} \quad$ Weight of char formed by the decomposition of hemicellulose in model-i

$\left[C_{\mathrm{L}}\right]_{i} \quad$ Weight of char formed by the decomposition of hemicellulose in model-i

$[\mathrm{g}]$

$[H]_{i} \quad$ Weight of hemicellulose in model-i

$[\mathrm{g}]$

$[I S]_{\mathrm{m} 1} \quad$ Weight of intermediate solid in model-1

$[\mathrm{g}]$

$[L]_{i} \quad$ Weight of lignin in model-i

$\left[S_{B}\right] \quad$ Weight of solid component of biomass

$V_{G} \quad$ Volume of gas in packed bed

$V_{\mathrm{PB}} \quad$ Volume of packed bed

$\left[\mathrm{cm}^{3}\right]$

$\left[W_{\mathrm{B}}\right]_{\mathrm{ml}}$ Weight of biomass in model-1

$\left[\mathrm{cm}_{3}\right]$

$\left[W_{\mathrm{B}, 0}\right] \quad$ Initial weight of biomass

Greek symbol

$\rho_{\text {app. }} \quad$ Apparent density of packed bed of biomass $\left[\mathrm{g} / \mathrm{cm}^{3}\right]$

$\rho_{\mathrm{t}} \quad$ True density of $\operatorname{wood}(=1.5) \quad\left[\mathrm{g} / \mathrm{cm}^{3}\right]$

$\varepsilon \mathrm{PB} \quad$ Volume fraction of air in packed bed 


\section{文 献：References}

1）奥村幸彦，日エネ誌, 90(2), 122 (2011)：Okumura, Y., $J$. Jpn. Inst. Energy, 90 (2), $122(2011)$

2) Koufopanos, C. A., Papayannakos, N., Maschio, G., Lucchesi, A., Can.J.Chem.Eng., 69, 907 (1991)

3) Won, C. P, Arvind, A., Howard, R. B., Combust. Flame, 157, $481(2010)$

4) Di Blasi, C., Prog. Energy Comb. Sci., 34, 47 (2008)

5）田之上健一郎, ウィディアウィジャヤンティ, 山崎慶, 川中隆司，吉田篤史，西村龍夫，谷口美希，笹内謙一，日 エネ誌, 89(10), 948(2010) : Tanoue, K., Widya, W., Yamasaki, K., Kawanaka, T., Yoshida, A., Nishimura, T., Taniguchi, M., Sasauchi, K., J. Jpn. Inst. Energy, 89 (10), 948 (2010)

6) 田之上健一郎, 西村龍夫, 日名内竜也, 内田一也, 谷口美 希，笹内謙一，エネルギー・資源，28-3，186(2007)： Tanoue, K., Nishimura, T., Hinauchi, T., Uchida, K.,
Taniguchi, M. and Sasauchi, K., Energy and Resources, 28-3, 186(2007)

7) Ayhan, D., Fuel, 76-5, 431(1997)

8) Thurner, F., Mann U., Ind.Eng. Chem. Proc.Des. Dev., 20, 482 (1981)

9) Di Blasi, C. and Branka, C., Ind. Eng. Chem. Res., 40-23, 5547 (2001)

10) Mohan, D., Pittman Jr., C. U., Steele, P. H., Energy Fuels, 20-3, 848(2006)

11) Miller, R. S., Bellan, J., Combust. Sci. Technol., 126, 97 (1997)

12) Varhegyi, G., Antal Jr., M.J., Szekely, T., Szabo, P., Energy Fuels, 3-3, 329(1989)

13) Capart, R., Khezami, L., Burnham, A. K., Thermo. ACTA, 4171,79(2004)

14) Chan, R. W. C., Krieger, B. B., J. Appl. Poly. Sci., 26-5, 1533 (1981) 